\title{
Mouse-Passaged Severe Acute Respiratory Syndrome-Associated Coronavirus Leads to Lethal Pulmonary Edema and Diffuse Alveolar Damage in Adult but Not Young Mice
}

Noriyo Nagata, ${ }^{*}$ Naoko Iwata, ${ }^{*}$ Hideki Hasegawa, ${ }^{*}$ Shuetsu Fukushi, ${ }^{\dagger}$ Ayako Harashima, ${ }^{*}$ Yuko Sato, ${ }^{*}$ Masayuki Saijo, ${ }^{\dagger}$ Fumihiro Taguchi, ${ }^{\neq}$ Shigeru Morikawa, ${ }^{\dagger}$ and Tetsutaro Sata*

From the Departments of Pathology, Virology I, ${ }^{\dagger}$ and Virology III, National Institute of Infectious Diseases, Musashimurayama, Tokyo, Japan

Advanced age is a risk factor of severe acute respiratory syndrome (SARS) in humans. To understand its pathogenesis, we developed an animal model using BALB/c mice and the mouse-passaged Frankfurt 1 isolate of SARS coronavirus (SARS-CoV). We examined the immune responses to SARS-CoV in both young and adult mice. SARS-CoV induced severe respiratory illness in all adult, but not young, mice on day 2 after inoculation with a mortality rate of 30 to $50 \%$. Moribund adult mice showed severe pulmonary edema and diffuse alveolar damage accompanied by virus replication. Adult murine lungs, which had significantly higher interleukin (II)-4 and lower IL-10 and IL-13 levels before infection than young murine lungs, rapidly produced high levels of proinflammatory chemokines and cytokines known to induce macrophage and neutrophil infiltration and activation (eg, tumor necrosis factor- $\alpha$ ). On day 2 after inoculation, young murine lungs produced not only proinflammatory cytokines but also IL-2, interferon- $\gamma$, IL-10, and IL-13. Adult mice showed early and acute excessive proinflammatory responses (ie, cytokine storm) in the lungs after SARS-CoV infection, which led to severe pulmonary edema and diffuse alveolar damage. Intravenous injection with anti-tumor necrosis factor- $\alpha$ antibody 3 hours after infection had no effect on SARS-CoV infection. However, intraperitoneal interferon- $\gamma$ injection protected adult mice from the lethal respiratory illness. The experimental model described here may be useful for elucidating the pathophysiology of SARS and for evaluating therapies to treat
SARS-CoV infection. (Am J Pathol 2008, 172:1625-1637; DOI: 10.2353/ajpath.2008.071060)

In the severe acute respiratory syndrome-associated coronavirus (SARS-CoV) epidemic of winter 2002 to 2003, $\sim 800$ people ( $10 \%$ of the $>8000$ SARS patients) suffered progressive respiratory failure and died. ${ }^{1-5}$ Common symptoms of SARS include fever, nonproductive cough, myalgia, and dyspnea. An age of 60 years or older, co-morbid disease, male sex, high neutrophil counts, and several biochemical abnormalities are associated with poor outcomes. ${ }^{6-10}$

The SARS-CoV spike (S) protein mediates the infection of cells bearing an appropriate receptor. ${ }^{11}$ One such receptor is angiotensin-converting enzyme 2 (ACE2), which binds SARS-CoV S protein with high affinity. ${ }^{11-14}$ That the binding of SARS-CoV to ACE2 may contribute to SARS-CoV-associated pathology is suggested by several reports showing that angiotensin II expression promotes severe lung failure on acute lung injury whereas ACE2 expression protects from lung injury. ${ }^{15,16}$ However, it is likely that the acute lung injury caused by SARS-CoV infection is also attributable to a complex pathophysiological process in which inflammatory cytokines released by activated alveoli macrophages induce immune system dysregulation. ${ }^{17-20}$

To understand the pathogenesis of SARS-CoV, the SARS-CoV susceptibility of experimental animals such as monkeys, cats, ferrets, mice, pigs, guinea pigs, ham-

Supported by the Ministry of Health, Labor, and Welfare, Japan (grant-in aid for research on emerging and re-emerging infectious diseases); and the Ministry of Education, Culture, Sports, Science, and Technology, Japan (grant-in-aid for scientific research no. 17790313).

Accepted for publication February 22, 2008.

Supplemental material for this article can be found on http://ajp. amjpathol.org.

Address reprint requests to Noriyo Nagata, D.V.M., Ph.D., Department of Pathology, National Institute of Infectious Diseases, Gakuen 4-7-1, Musashimurayama, Tokyo 208-0011, Japan. E-mail: nnagata@nih.go.jp. 
sters, chickens, and rats has been investigated. 2,4,21-28 All of these animals are susceptible to SARS-CoV after intrarespiratory inoculation and exhibit virus excretion in pharyngeal or nasal swabs, histopathological pulmonary lesions, and seroconversion. However, the course of infection in these animals is shorter than that in humans.

As in humans, an advanced age correlates positively and independently with adverse outcomes and is a predictor of mortality in animal models. ${ }^{6-10}$ Moreover, SARS$\mathrm{CoV}$ isolates replicate better in aged BALB/c mice than in younger mice. ${ }^{29}$ It is likely that the correlation between poor outcome and advanced age reflects the weakened immune responses of the elderly, in particular their impaired cytokine responses. This is significant because cytokines regulate the immune response to infection. Indeed, analysis of the cytokine responses of elderly individuals to respiratory infections that lead to severe pulmonary diseases (eg, Listeria monocytogenes, respiratory syncytial virus, influenza virus) $)^{30-33}$ have revealed unbalanced Th1-type and Th2-type responses.

We recently succeeded in establishing a rat model of SARS using rat-passaged SARS-CoV. ${ }^{34}$ Although the ratpassaged SARS-CoV was not lethal, it induced more severe pathological lesions in adult F344 rats than in young rats. We found that the severe inflammation in the adult rats was associated with high levels of inflammatory cytokines in the serum and lung homogenates, especially interleukin (IL)-6, along with low levels of the immunosuppressive cytokine IL-10. IL-6 is an inflammatory cytokine that is produced by monocytes, leukocytes, endothelial cells, fibroblasts, and alveolar epithelial cells. SARS patients have significantly elevated serum IL-6 levels. ${ }^{19}$ IL-10 is produced by macrophages, Th2 lymphocytes, and $\mathrm{B}$ cells and inhibits tumor necrosis factor (TNF)- $\alpha$ production and neutrophil activation in lipopolysaccharide-induced acute lung injury, thereby suppressing lung tissue injury. ${ }^{35}$ It has been reported that serum IL-10 levels increase in SARS patients during the convalescence phase. ${ }^{19}$

In this study, we established a new and more useful experimental small animal model for SARS by using $\mathrm{BALB} / \mathrm{c}$ mice and mouse-passaged SARS-CoV. This model allows us to better characterize the virus-host relationship and determine which immune responses are antiviral and which are pathogenic. Here, we sought to determine why SARS-CoV infection is more frequently lethal in elderly patients by comparing SARS-CoV-infected adult and young mice in terms of their pulmonary pathology and immune responses.

\section{Materials and Methods}

\section{Virus and Cells}

The Frankfurt 1 isolate of SARS-CoV used in this study was kindly supplied by Dr. John Ziebuhr, Institute of Virology and Immunology, University of Würzburg, Würzburg, Germany. The virus was propagated twice in Vero E6 cells purchased from American Type Cell Collection (Manassas, VA) that were cultured in Eagle's minimal essential medium (MEM) containing $5 \%$ fetal bovine serum, $50 \mathrm{IU}$ of penicillin $\mathrm{G}$, and $50 \mu \mathrm{g}$ of streptomycin per $\mathrm{ml}$. Titers of this stock virus were expressed as $50 \%$ of the tissue culture infectious dose $\left(\mathrm{TCID}_{50}\right) / \mathrm{ml}$ on Vero E6 cells, which was calculated according to the BehrensKärber method. Work with infectious SARS-CoV was performed under biosafety level 3 conditions. Compared to the original virus, the Frankfurt 1 isolate used in our laboratory has one amino acid change at position 641 (His to Tyr) in the S protein and another in open reading frame (ORF) 1a 429 (Ala to Ser). These changes presumably arose during the passage through Vero E6 cells.

\section{Mice}

Female 4-week-old or 6-month-old BALB/c mice were purchased from Japan SLC (Shizuoka, Japan) and maintained in specific pathogen-free facilities. On experimental infection, these animals were housed in biosafety level 3 animal facilities. These animal experiments were approved by the Animal Care and Use Committee of the National Institute of Infectious Diseases, Tokyo, Japan.

\section{Serial in Vivo Passage of SARS-CoV in Mice}

The Frankfurt 1 isolate of SARS-CoV was serially passaged 10 times in 4-week-old female BALB/c mice, as follows. After intranasal inoculation, three mice were sacrificed on day 3 after inoculation and their bronchoalveolar wash fluids were collected. These bronchoalveolar fluids were then used to inoculate three additional BALB/C mice, whose bronchoalveolar fluids on day 3 after inoculation were used to inoculate fresh mice. After 10 such passages in mice, the lungs were removed under sterile conditions, washed three times, and homogenized in $1 \mathrm{ml}$ of phosphate buffer containing $0.1 \%$ bovine serum albumin, $20 \mathrm{IU}$ of penicillin G, $20 \mu \mathrm{l}$ of streptomycin, and $1 \mu \mathrm{g}$ of amphotericin B per $\mathrm{ml}$. The lung homogenates were centrifuged at $1000 \times g$ for 20 minutes, and $1 \mathrm{ml}$ of the supernatants in $10 \mathrm{ml}$ of MEM containing $2 \%$ fetal bovine serum were used to infect Vero E6 cells. After 1 hour of adsorption, the inoculum was removed and MEM containing $2 \%$ fetal bovine serum was added. The cell cultures were incubated at $37^{\circ} \mathrm{C}$ with $5 \% \mathrm{CO}_{2}$ for 2 days and then treated once with freezethawing. After centrifugation at $1000 \times g$ for 20 minutes, the supernatants (referred to here as F-musX-VeroE6) were used as the virus inoculum. Compared to the original virus, F-musX-VeroE6 has amino acid mutations in the S protein at positions 480 (Asp to Glu) and 641 (His to Tyr); The latter change is identical to one of the mutations found in the Frankfurt 1 isolate. In the completely sequenced genome, F-musX-VeroE6 also has two additional mutations in ORF1a 3534 (Phe to Leu) and ORF1ab 5172 (Thr to lle). The mutation in ORF1a 429 found in the Frankfurt 1 isolate was not present.

\section{Experimental Mouse Infection}

Mice were anesthetized by intraperitoneal injection with a $0.1 \mathrm{ml} / 10 \mathrm{~g}$ body weight mixture of $1.0 \mathrm{mg}$ ketamine and 
$0.02 \mathrm{mg}$ xylazine. The animals were then inoculated intranasally in the left nostril with the Frankfurt 1 isolate or F-musX-VeroE6 $\left(2 \times 10^{6} \mathrm{TCID}_{50}\right.$ in $\left.20 \mu \mathrm{l}\right)$ and observed for clinical signs. Body weight was measured daily for 10 or 21 days. Infected animals were also sacrificed at various time points after inoculation to analyze virus replication, hematology, cytokine expression, and pathology ( $n=3$ in each group).

\section{Virus Isolation and Titration}

Twenty percent (w/v) tissue homogenates of the lung, maxilla (including the nasal cavity), cervical lymph node, spleen, liver, and kidney were prepared in MEM containing $2 \%$ fetal bovine serum, $50 \mathrm{IU}$ penicillin G, $50 \mu \mathrm{g}$ streptomycin, and $2.5 \mu \mathrm{g}$ amphotericin B per ml (MEM2FBS). Bronchoalveolar and nasal wash fluids were also collected for analysis of virus replication. Viral infectivity titers of respiratory tract and wash fluids were determined as described above. Virus isolation from other tissues was performed by blind passage after freezing and thawing the first-round passage using Vero E6 cells.

\section{Hematological Analysis}

Total blood cell counts in peripheral blood collected in sodium-heparinized tubes were measured by an autoanalyzer (Cell Tuck; Nihon Koden, Tokyo, Japan). Neutrophil, lymphocyte, monocyte, eosinophil, and basophil counts were determined by microscopic analysis.

\section{Flow Cytometric Analysis}

Antibodies used for flow cytometry were anti-CD4-phycoerythrin-Cy5 (eBioscience, San Diego, CA), anti-CD8 $\beta$ phycoerythrin (Santa Cruz Biotechnology, Santa Cruz, $\mathrm{CA}$ ), and anti-pan-NK cells-fluorescein isothiocyanate (eBioscience). Cells incubated with these surface-binding antibodies were fixed in $2 \%$ paraformaldehyde in phosphate-buffered saline (PBS) and subjected to flow cytometry (EPICS Elite; Beckman Coulter, Fullerton, CA) using EXPO cytometer software (Beckman Coulter).

\section{Cytokine Multiplex Analysis}

Homogenized lung tissue samples were diluted 1:1 with cell extraction buffer $[10 \mathrm{mmol} / \mathrm{L}$ Tris, $\mathrm{pH} 7.4,100 \mathrm{mmol} / \mathrm{L}$ $\mathrm{NaCl}, 1 \mathrm{mmol} / \mathrm{L}$ EDTA, $1 \mathrm{mmol} / \mathrm{L}$ EGTA, $1 \mathrm{mmol} / \mathrm{L} \mathrm{NaF}, 20$ $\mathrm{mmol} / \mathrm{L} \mathrm{Na} \mathrm{P}_{2} \mathrm{O}_{7}, 2 \mathrm{mmol} / \mathrm{L} \mathrm{Na} \mathrm{Na}_{3}, 1 \%$ Triton X-100, $10 \%$ glycerol, $0.1 \%$ sodium dodecyl sulfate, and $0.5 \%$ deoxycholate (BioSource International, Inc., Camarillo, $\mathrm{CA})$ ], incubated for 30 minutes on ice with vortexing at 10 minute intervals, and then centrifuged at 15,000 $\times \mathrm{g}$ for 10 minutes at $4^{\circ} \mathrm{C}$. Supernatants were diluted $1: 5$ in assay diluent of the Mouse Cytokine 20-Plex antibody bead kit (BioSource International). Sera and the $20 \%$ lung homogenate supernatants were subjected to ultraviolet irradiation for 10 minutes to inactivated virus infectivity and stored at $-80^{\circ} \mathrm{C}$ until they were used to determine the presence of mouse cytokines, namely, basic fibroblast growth factor, GM-CSF, interferon (IFN)- $\gamma, \mathrm{IL}-1 \alpha, \mathrm{IL}-1 \beta$, IL-2, IL-4, IL-5, IL-6, IL-10, IL-12p40/p70, IL-13, IL-17, IP-10, keratinocyte chemoattractant (KC), monocyte chemoattractant protein 1 (MCP-1), MIG, MIP-1 $\alpha$, TNF- $\alpha$, and vascular endothelial growth factor (VEGF), by using the Mouse Cytokine 20-Plex antibody bead kit and Luminex 100TM (Luminex Co., Austin, TX).

\section{Histopathological and Immunohistochemical Analysis}

Animals ( $n=3$ in each group) were anesthetized and perfused with $2 \mathrm{ml}$ of $10 \%$ phosphate-buffered formalin. Fixed lung, heart, kidney, liver, spleen, small and large intestine, brain, spinal cord, and maxilla (including nasal cavity) tissues were routinely embedded in paraffin, sectioned, and stained with hematoxylin and eosin. Maxilla samples were decalcified in phosphate-buffered saline ( $\mathrm{pH} 7.4$ ) plus 10\% EDTA before being embedded. Immunohistochemical detection of the SARS-CoV antigens was performed on paraffin-embedded sections, as follows. After deparaffinizing with xylene, sections were rehydrated in ethanol and immersed in PBS. Antigens were retrieved by hydrolytic autoclaving for 20 minutes at $121^{\circ} \mathrm{C}$ in $10 \mathrm{mmol} / \mathrm{L}$ sodium citrate-sodium chloride buffer ( $\mathrm{pH}$ 6.0). After cooling, the sections were immersed in PBS. Endogenous peroxidase was blocked by incubation in $1 \%$ hydrogen peroxide in methanol for 30 minutes. After washing in PBS, the sections were incubated with normal rabbit serum for 5 minutes, and then with rabbit antibody against SARS-CoV ${ }^{32,36}$ overnight at $4^{\circ} \mathrm{C}$. After three washes in PBS, the sections were incubated with biotin-conjugated anti-rabbit IgG for 30 minutes at $37^{\circ} \mathrm{C}$, followed by reaction with streptavidin-peroxidase for 30 minutes at room temperature. Peroxidase activity was detected by development with diaminobenzidine containing hydrogen peroxide. Nuclei were counterstained by hematoxylin.

\section{Double Immunofluorescence Staining}

SARS-CoV- and mock-infected adult and young mice were euthanized 1,3 , and 5 days after inoculation by exsanguination under excess ether anesthesia, after which the lungs were harvested for pathological examination (three mice per group). Mock infection was performed by using MEM containing $2 \%$ fetal bovine serum. For staining with anti-Mac-3 and anti-surfactant D (SP-D) antibodies and to detect SARS-CoV antigens, the lungs were fixed with $4 \%$ paraformaldehyde in PBS at $4^{\circ} \mathrm{C}$ for 15 to 18 hours and embedded in paraffin according to the manufacturer's instructions (BD Biosciences Pharmingen, San Diego, CA). The paraffin-embedded sections were then subjected to a double-immunofluorescence staining method ${ }^{37}$ using a polyclonal rabbit antibody against SARS-CoV ${ }^{36}$ and the SKOT9 monoclonal mouse antibody against nucleocapsid protein ${ }^{38}$ or a monoclonal rat anti-Mac-3 antibody against mouse mononuclear phagocytes (BD Biosciences Pharmingen), and a poly- 
clonal rabbit anti-SP-D antibody (Chemicon International, Inc., Billerica, MA). Briefly, after deparaffinization with xylene, the sections were rehydrated in ethanol and immersed in PBS. Antigens were retrieved by hydrolytic autoclaving for 10 minutes at $121^{\circ} \mathrm{C}$ in $10 \mathrm{mmol} / \mathrm{L}$ sodium citrate-sodium chloride buffer ( $\mathrm{pH}$ 6.0). After cooling, the sections were immersed in PBS, and then incubated with primary antibodies overnight at $4^{\circ} \mathrm{C}$. To block background staining, normal donkey serum or the M.O.M. immunodetection kit for primary mouse monoclonal antibody (Vector Laboratories, Burlingame, CA) were used according to the manufacturer's instructions. After three washes in PBS, the sections were incubated for $30 \mathrm{~min}$ utes at $37^{\circ} \mathrm{C}$ with biotin-conjugated secondary antibodies, ie, a donkey anti-rat serum (Jackson ImmunoResearch, West Grove, PA) to detect the Mac-3 antibody or a goat anti-rabbit serum (Jackson ImmunoResearch) to detect the SP-D antibody. After three washes in PBS, the sections were incubated with streptavidin-Alexa Fluor 488 (Molecular Probes, Eugene, OR) for 60 minutes at room temperature. After three washes in PBS, to detect the SARS-CoV antibodies (the SKOT9 or the rabbit antibody), the sections were incubated with anti-rabbit or anti-mouse Alexa Fluor 568 (Molecular Probes) for 60 minutes at room temperature. The sections were counterstained with TO-PRO-3 nucleic acid staining (Molecular Probes) and images were captured and analyzed by confocal laser microscopy (Fluoview, FV1000; Olympus, Tokyo, Japan).

\section{Anti-Mouse TNF- $\alpha$ Antibody or IFN- $\gamma$ Treatment in Vivo}

Three hours after intranasal inoculation of F-musX-VeroE6 $\left(2 \times 10^{6} \mathrm{TCID}_{50}\right.$ in $\left.20 \mu \mathrm{l}\right)$, adult (6-month-old) BALB/C females mice were injected intravenously with $100 \mu \mathrm{l}$ of anti-mouse TNF- $\alpha$ rat monoclonal antibody $(1 \mu \mathrm{g} / \mu \mathrm{l}$, Biosource), or isotype-matched control rat antibody $(1 \mu \mathrm{g} / \mu \mathrm{l}$; MP Biomedicals, Solon, OH) in PBS, or injected intraperitoneally with $100 \mu \mathrm{l}$ of recombinant mouse IFN- $\gamma(0.05$ $\mu \mathrm{g} / \mu \mathrm{l}$; R\&D Systems, Minneapolis, MN) or intraperitoneal injection with $100 \mu \mathrm{l}$ of $\mathrm{PBS} / 0.1 \%$ bovine serum albumin was used as control. At least two independent experiments were performed ( $n=5$ or 8 per group).

\section{Evaluation of Blood Permeability}

SARS-CoV- and mock-infected mice were injected intravenously with $100 \mu$ l of $1 \%$ Evans blue dye (Tokyo Kasei, Tokyo, Japan) 1 hour before sacrifice ( $n=3$ in each group). Mock infection was performed by using MEM containing $2 \%$ fetal bovine serum. After perfusion with isotonic saline, the whole lung was removed and immersed in 10\% phosphate-buffered formalin. The fixed lungs were immediately frozen in cold acetone with dry ice in $100 \%$ O.C.T. compound (Sakura Finetechnical Co. Ltd., Tokyo, Japan). Cryosections (5 $\mu \mathrm{m})$ (CM1900; Leica, Wetzlar, Germany) were mounted on MAS-coated slides (Matsunami, Osaka, Japan), air-dried, and examined with a fluorescence microscope.

\section{Statistical Analysis}

Statistical significance was determined by Student's $t$ test. $P$ values $<0.05$ were considered significant.

\section{Results}

\section{The Virulence and Pathogenicity of SARS-CoV in Mice Is Enhanced by Serial Mouse Passaging}

The Frankfurt 1 isolate was passaged twice on VeroE6 cells and then serially passaged 10 times in young BALB/c mice (4-week-old females) by intranasal inoculation of bronchoalveolar fluids from infected mice. The F-musX-VeroE6 strain showed higher replication and pathogenicity in the respiratory tract of young BALB/C mice than the original Frankfurt 1 isolate, as follows (Figure $1, A-E)$. On day 3 after inoculation, F-musX-VeroE6 replication in the lung washes was higher than that of the original Frankfurt 1 isolate $(P=0.055)$ but lower in the nasal washes $(P<0.01)$ (Figure $1 A)$. Compared to Frankfurt 1 isolate-inoculated young mice, the F-musX-VeroE6inoculated young mice also evinced more lung inflammation, as shown by neutrophil, macrophage, and lymphocyte infiltration and virus antigen-positive cells in the alveolar spaces (Figure 1, B-E). However, the F-musX-VeroE6-inoculated young mice did not develop any obvious respiratory illnesses, although they did show transient weight loss for a few days after inoculation (data not shown).

Because advanced age is associated with higher mortality in human SARS patients and SARS-CoV replicates better in aged mice, ${ }^{6-10,29}$ we experimentally infected 6-month-old (adult) female BALB/c mice with F-musXVeroE6 or the Frankfurt 1 isolate. Although none of the mice showed clinical signs of illness after intranasal inoculation with Frankfurt 1 isolate, all F-musX-VeroE6-inoculated mice became severely ill, as revealed by significant weight loss ( $20 \%$ of their initial body weight), hunching, ruffled fur, and dyspnea on day 2 after inoculation (Figure 1F). Three of the ten mice became moribund and died of severe respiratory illness on days 3, 6, and 10 after inoculation ( $30 \%$ mortality rate). The surviving animals recovered their body weight during days 4 to 6 after inoculation.

\section{Pathogenesis of Mouse-Passaged SARS-CoV in Young and Adult BALB/c Mice}

These results demonstrated that serial in vivo passage of SARS-CoV in mice increased the virulence of the virus, especially in adult mice. Thus, we characterized the clinical and pathological features of F-musX-VeroE6-infected young and adult mice up until day 5 after inoculation in more detail. The young mice again showed transient weight loss of up to $8.2 \%$ ( $S D=3.7 \%$ ) during days 2 to 4 after inoculation but had recovered their weight by day 5 after inoculation (Figure 2A). In contrast, the adult mice showed continuous weight loss of up to $23.0 \%$ (SD = 
4.5\%) of their initial body weight that continued until day 5 after inoculation. All adult mice showed virtually identical clinical manifestations during days 1 to 2 after inoc-

A
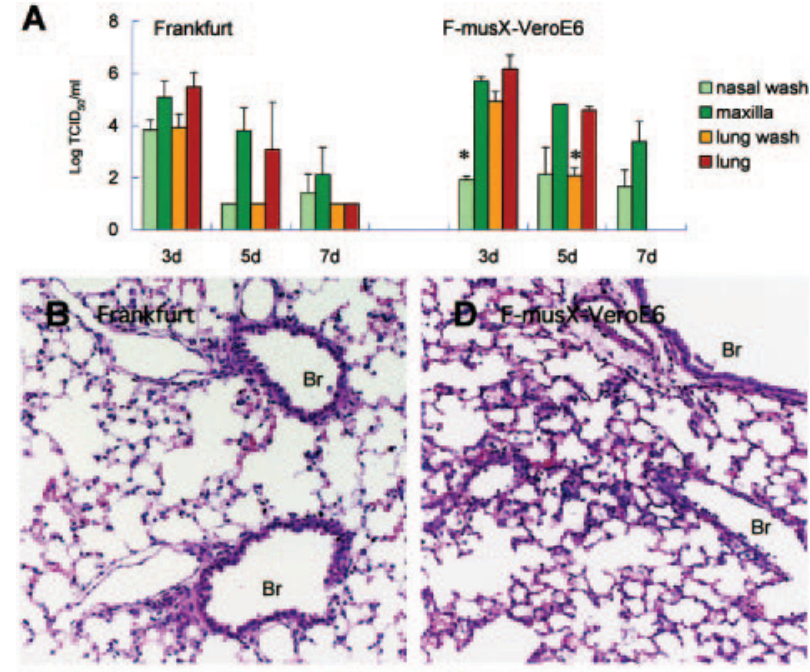

c

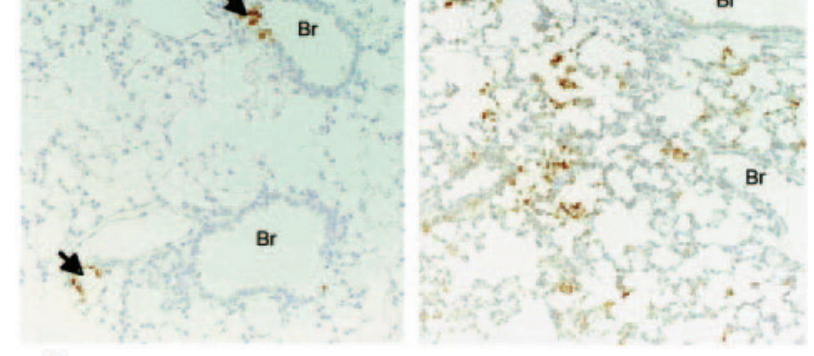

F
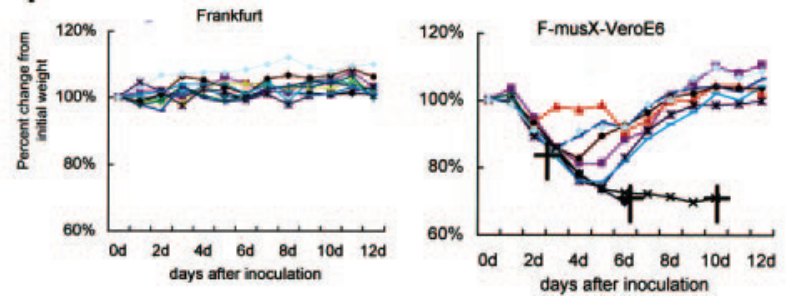

Figure 1. Comparison of the replication and pathogenicity of F-musXVeroE6 and the original Frankfurt 1 isolate in young (4 weeks old) (A-E) and adult ( 6 months old) (F) female BALB/c mice. A: Virus titers in nasal wash fluids, homogenates of maxilla (including the nasal cavity), lung wash fluid, and lung homogenates of young mice on days 3,5, and 7 after inoculation ( $n=3$ per group). The detection limit was $10^{1.5} \mathrm{TCID}_{50} / \mathrm{g}$ of tissue. Asterisks indicate statistically significant differences between $\mathrm{F}$ musX-VeroE6 and the Frankfurt isolate $(P<0.05)$. B-E: Histopathological features of the lungs of young mice on day 3 after inoculation. B: After infection with the Frankfurt 1 isolate, inflammatory infiltrates in the lung were not detected. Moreover, very few alveolar pneumocytes and alveolar duct and alveolus epithelial cells were SARS-CoV antigen-positive (C arrowheads). In contrast, extensive cellular infiltration (D) and many virus antigen-positive cells (E) were seen in the alveolar area after FmusX-VeroE6 infection. F: Clinical illness in individual 6-month-old adult BALB/c mice after Frankfurt isolate or F-musX-VeroE6 infection $(n=10$ per group). Shown are the changes in body weight (expressed as percentages of the body weight on day 0). The mean initial body weight of the two mouse groups (on day 0 ) were $24.72 \pm 1.04 \mathrm{~g}$ and $25.44 \pm 1.55 \mathrm{~g}$, respectively. Significant differences in body weight change were detected on days 2 to 8 after inoculation. For example, the average body weight F-musX-VeroE6-infected adult mice on day 5 after inoculation was $83.4 \pm 9.88 \%$ of the mean day 0 body weight. This was significantly lower than the average body weight change of Frankfurt 1 isolate-infected adult mice on day 5 after inoculation $(102.4 \pm 2.99 \%)$. Three F-musX-VeroE6-infected adult mice died (crosses) of severe pulmonary edema on days 3,6 , and 10 after inoculation. ulation (such as hunching and ruffled fur) that were not observed in the young mice. Severe respiratory symptoms such as dyspnea were also observed in the adult mice from 2 days after inoculation onwards. In this experiment, $50 \%$ of the adult mice had died by day 5 after inoculation.

The lungs of infected young and adult mice were weighed on days 0 to 5 after inoculation. The progressive increase in lung weight of the adult mice suggested the development of pulmonary edema (Figure 2, B and C). By day 5 after inoculation, the adults showed significantly greater lung weight changes than the young mice $(P<$ 0.01). The lungs of infected young and adult mice were also subjected to histopathological analysis on days 1 to 5 after inoculation (Figure 3, A-H). On day 1 after inoculation, both young and adult mice had antigen-positive epithelial cells in the bronchi and alveoli. The antigenpositive cells in the alveoli were considered on the bases of morphology and immunohistochemistry to be mainly type II pneumocytes (Figure 3, A and E; see Supplemental Figure $\mathrm{S} 1$ at $h$ ttp://ajp.amjpathol.org). On day 2 after inoculation, antigen-positive atrophic and necrotic cells were seen in the alveolar area of both mice (Figure 3B). In addition, antigen-positive activated alveolar macrophages associated with inflammatory infiltrations were seen in the alveolar area of adult mice (Figure 3F). No antigen-positive cells were seen in the bronchi on day 2 after inoculation or afterward in either young or adult mice. On day 3 after inoculation, the young mice had diffuse inflammatory infiltrates consisting mainly of mononuclear cells (Figure 3, C and D), and virus antigenpositive cells were seen in the alveolar area. Activated macrophages, lymphocytes, and neutrophils were seen in the alveoli on days 4 and 5 after inoculation. In contrast, the adult mice evinced severe pulmonary edema, and congestion on day 3 after inoculation (Figure 3, G and $\mathrm{H}$ ). In these mice, the main inflammatory cells around the adult blood vessels and alveolar area on days 3 to 5 after inoculation were neutrophils and activated macrophages. Fibrin deposition and hyaline membrane formation in the alveolar duct and alveoli were also observed (Figure $3 \mathrm{H}$ ), and microhemorrhages was seen in the alveolar area. The adult mice also had high virus titers in the lung and maxilla (including nasal cavity) and their fluid (Figure 2, D and E). After the infection, virus continued to be isolated from the cervical lymph nodes, spleen, liver, and kidneys of adult mice after day 2 after inoculation whereas virus could no longer be isolated from any young mouse tissue (apart from the lung) after this time point (Table 1).

\section{Different Immune Responses to SARS-CoV in Young and Adult Mice}

To analyze the immune responses of young and adult mice after infection with F-musX-VeroE6, we examined their peripheral blood white blood cell counts (Figure 4), and measured the levels of 20 different chemokines and cytokine levels in their plasma and lung homogenates (Figures 5 and 6). Before infection (day 0), the adult mice had significantly lower white blood cells counts, especially with regard to lymphocytes (including $\mathrm{CD} 4^{+}$and $\mathrm{CD} 8 \beta^{+} \mathrm{T}$ cells), than the 
A

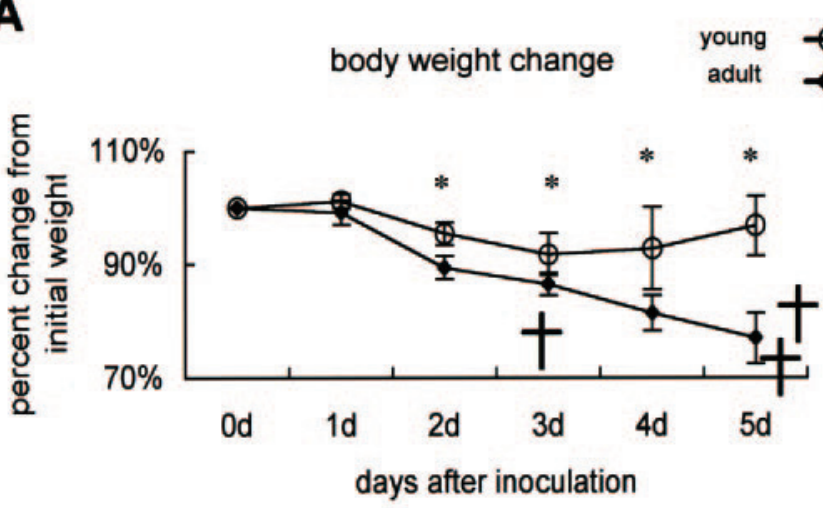

B

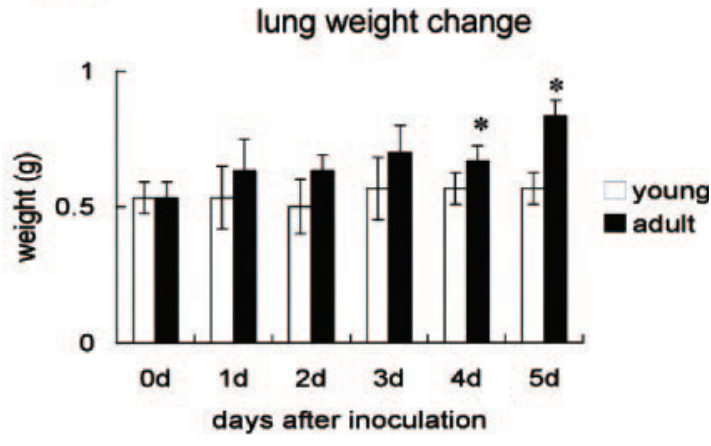

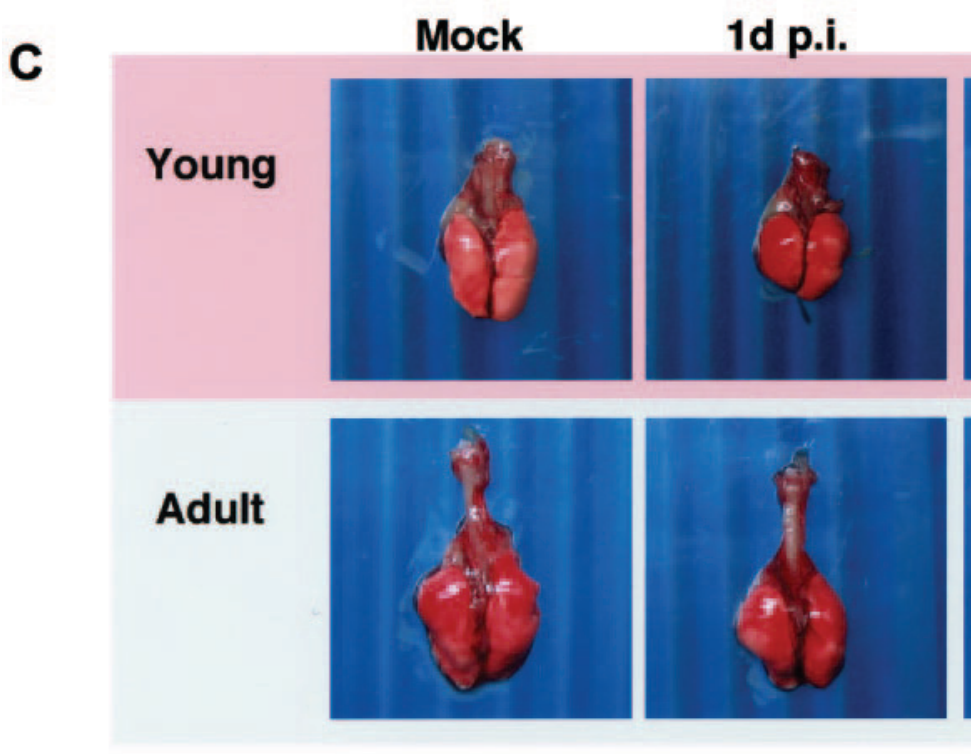

3d p.i.

5d p.i.

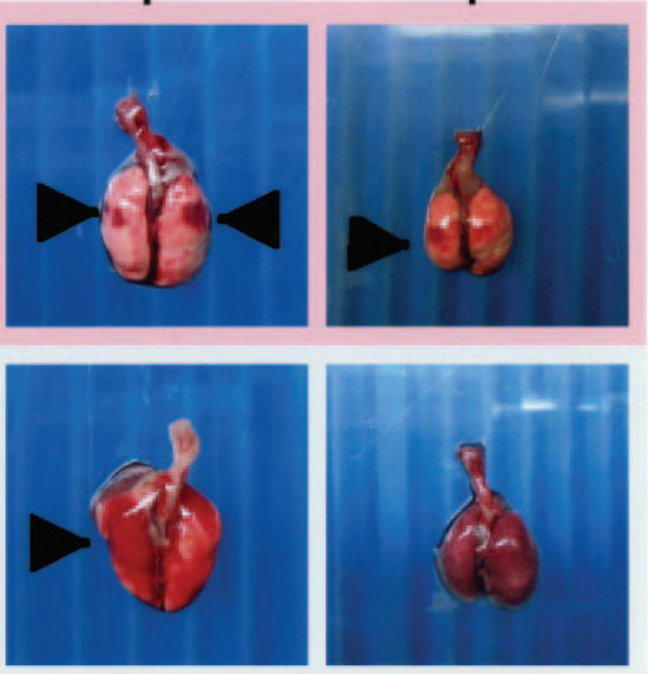

D

young mice

E

adult mice
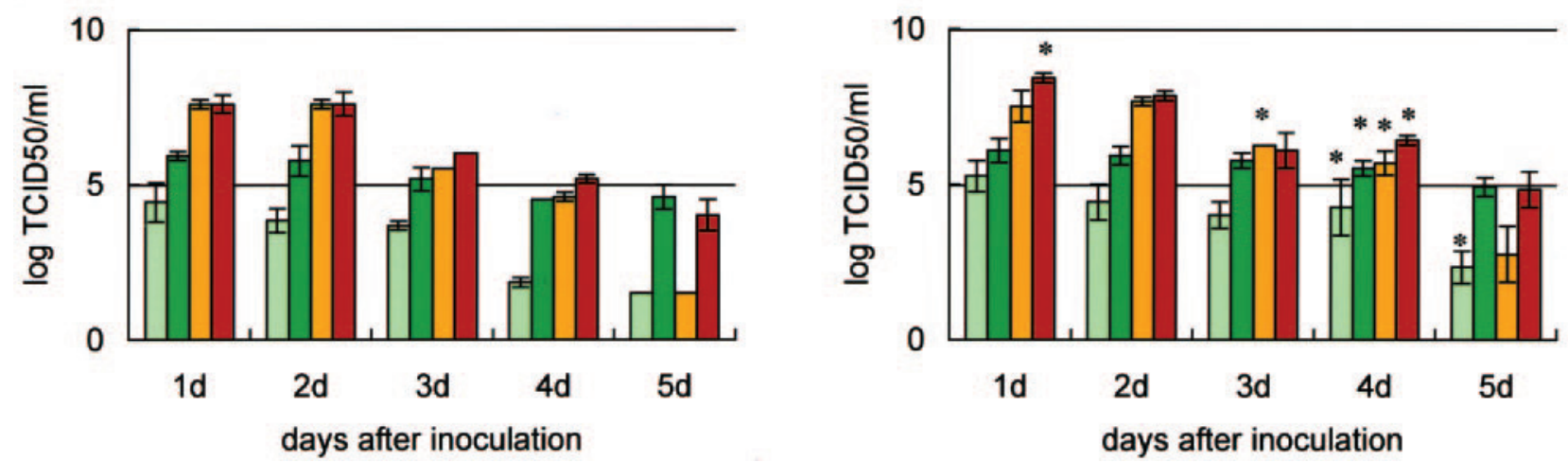

Figure 2. The pathophysiology induced by mouse-passaged SARS-CoV differs between young and adult mice. F-musX-VeroE6-infected young and adult mice were examined at the same time points after inoculation. Asterisks indicate statistically significant differences between young and adult mice $(P<0.05)$. A: Mean change in body weight (expressed as a percentage of the body weight on day 0$)(n=6$ per group). Three (50\%) of the adult mice became moribund and died (crosses) by day 5 after inoculation. B: To assess the lungs for pulmonary edema, the lungs were weighed after mice were sacrificed on days 1 to 5 after inoculation by exsanguination under anesthesia ( $n=3$ per group). C: Lungs from virus- and mock-infected young and adult mice obtained at the indicated time points after inoculation. Arrowheads indicate focal congestion. On day 5 after inoculation, a moribund adult mouse had dark red congested lungs. $\mathbf{D}$ and $\mathbf{E}$ : Virus titers in the nasal (pale green bar) and lung (yellow bar) wash fluids and homogenates of the maxilla (including nasal cavity, green bar) and lung (orange bar) on days 1 to 5 after inoculation $\left(n=3\right.$ per group). The detection limit was $10^{1.5}$ TCID ${ }_{50} / g_{\text {of tissue. }}$

young mice (Figure 4). After infection, the neutrophil counts in the adult mice increased; however, this change was not observed in the young mice. In young mice, relative to counts on day 0 , lymphocyte counts decreased signifi- cantly $(P<0.05)$ on days 2,3 , and 4 after inoculation but then recovered, CD8 $\beta^{+}$T-cell counts decreased significantly on day 2 and then recovered, and CD4 ${ }^{+}$T-cell counts decreased slightly and then showed a significant 


\section{young mice}

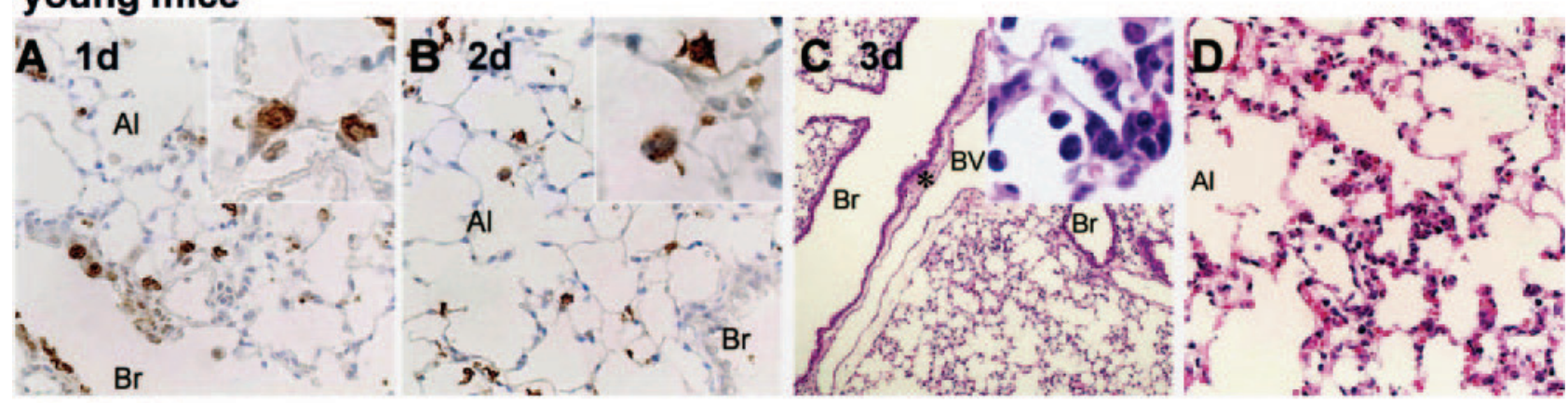

\section{adult mice}

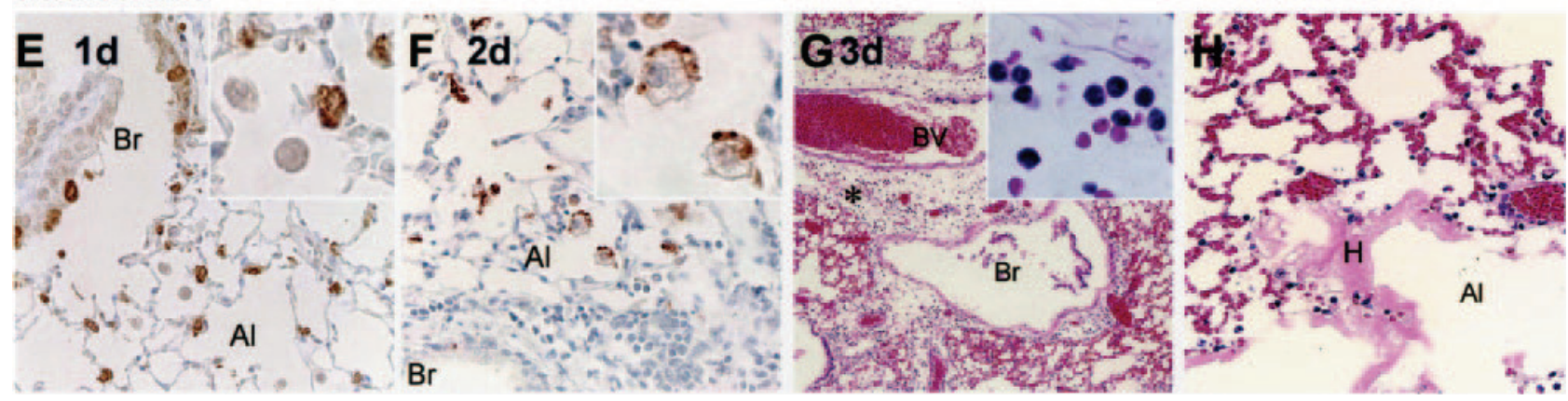

Figure 3. Histopathological findings in the lungs of young (A-D) and adult (E-H) mice on days 1 (A, E), 2 ( $\mathbf{B}, \mathbf{F})$, and $3(\mathbf{C}, \mathbf{D}, \mathbf{G}, \mathbf{H})$ after inoculation. Br, bronchi; $\mathrm{Al}$, alveoli; BV, blood vessel; $\mathrm{H}$, hyaline membrane. The results in each panel are representative of at least three mice for each panel. Immunohistochemical staining with anti-SARS-CoV-specific antibody revealed virus antigen-positive cells in pulmonary epithelial cells of the bronchi and alveolar area, and type II pneumocytes (inset) in both young and adult mice on day 1 after inoculation (A, E). On day 2 after inoculation, atrophic cells in the alveolar area of young mice were positive for virus antigen (B, inset). In adult mice at the same time point activated alveolar macrophages presented in the alveolar space were also positive for virus antigen (F, inset). On day 3 after inoculation, the young mice showed slight inflammatory mononuclear cell infiltration in the alveolar area (C, inset and $\mathbf{D}$ ) but the adult mice exhibited massive pulmonary edema and inflammatory polynuclear leukocyte infiltration around blood vessels (G, inset). H: They also showed hyaline membrane formation in the alveolar duct.

increase on day 5. In contrast, although the lymphocyte counts of adult mice also dropped and were significantly lower than day 0 counts on days 3 and 4, they did not evidence an improvement on day 5 after inoculation. Moreover, the $\mathrm{CD} 8 \beta^{+} \mathrm{T}$ - and $\mathrm{CD} 4^{+} \mathrm{T}$-cell counts of the adult mice also showed significant drops on days 1,3 , and 4 after inoculation $(P<0.05)$ but had recovered poorly on day 5 after inoculation, unlike the counts in young mice. With regard to the PanNK ${ }^{+}$cells counts, both the young and adult mice showed a marked drop on day 1 after inoculation that was followed by a brief recovery and then another loss on day 4 after inoculation cell count loss at day 1 and 5 days after inoculation compared with 0 days after inoculation in adult mice $(P<0.05)$.
With regard to the cytokine responses of the mice, the lung homogenates of adult mice on day 1 after inoculation had significantly higher levels of monocyterelated chemokines [ie, MCP-1, macrophage inflammatory protein 1 (MIP-1), and IFN- $\gamma$-inducible protein 10 (IP-10)] than those from young mice (Figure 5). In contrast, on day 2 after inoculation, the lung homogenates of young mice exhibited elevated levels of these three cytokines as well as $\mathrm{KC}$, monokine induced by IFN- $\gamma(\mathrm{MIG})$, and vascular endothelial growth factor (VEGF) (Figure 5). Compared to young mice, the lung homogenates of adult mice on day 1 after inoculation also had higher levels of IL- $1 \alpha, \mathrm{IL}-1 \beta$, and TNF- $\alpha$, and on day 3 after inoculation, higher levels of IL-6 were

Table 1. Virus Isolation from Different Tissues of F-musX-VeroE6-Infected BALB/c Mice at Various Time Points after Inoculation $(n=3$ per Time Point)

\begin{tabular}{|c|c|c|c|c|c|c|c|c|c|c|}
\hline \multirow[b]{2}{*}{ Days after inoculation } & \multicolumn{5}{|c|}{ Young mice (4-week-old BALB/c) } & \multicolumn{5}{|c|}{ Adult mice (6-month-old BALB/c) } \\
\hline & Lung & Cervical L/N & Spleen & Liver & Kidney & Lung & Cervical L/N & Spleen & Liver & Kidney \\
\hline 0 days & $0^{*}$ & 0 & 0 & 0 & 0 & 0 & 0 & 0 & 0 & 0 \\
\hline 1 day & 3 & 3 & 3 & 1 & 0 & 3 & 3 & 3 & 3 & 0 \\
\hline 2 days & 3 & 3 & 2 & 2 & 0 & 3 & 3 & 2 & 2 & 1 \\
\hline 3 days & 3 & 0 & 0 & 0 & 0 & 3 & 2 & 1 & 1 & 1 \\
\hline 4 days & 3 & 0 & 0 & 0 & 0 & 3 & 2 & 0 & 0 & 0 \\
\hline 5 days & 3 & 0 & 0 & 0 & 0 & 3 & 0 & 1 & 0 & 0 \\
\hline
\end{tabular}

${ }^{*}$ Number of virus isolation-positive animals.

L/N, lymph node. 

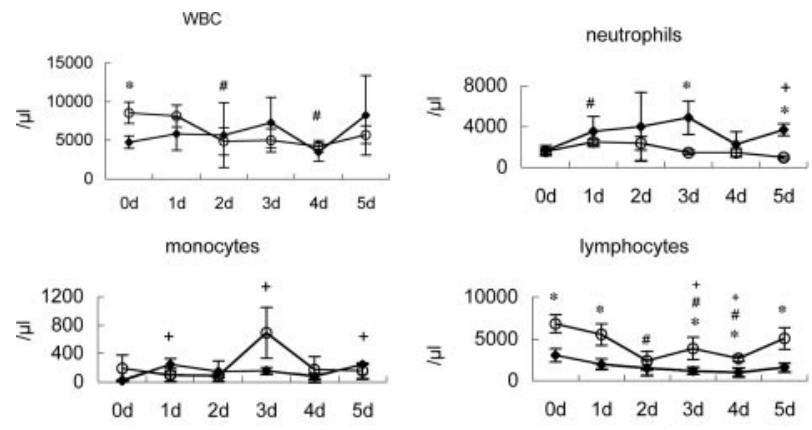

CD4+
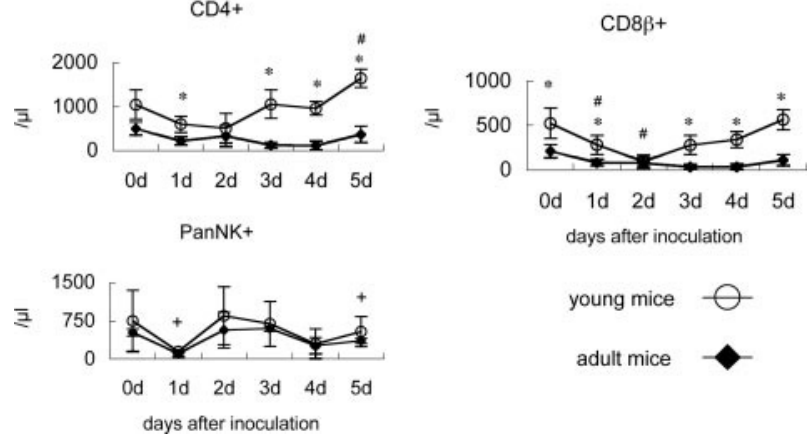

Figure 4. White blood cell (WBC) counts in young and adult mice throughout time after inoculation. Shown are total WBC, neutrophil, monocyte, lymphocyte, CD4-positive cell, CD8 $\beta$-positive cell, and NK cell counts in the peripheral blood of young and adult mice after intranasal inoculation with mouse-passaged SARS-CoV $(n=3) .{ }^{*} P<0.05$ indicate statistically significant differences between young and adult mice at the same time point. ${ }^{*} P<0.05$ and ${ }^{+} P<0.05$ indicate statistically significant differences within groups relative to day 0 in young or adult mice, respectively.

observed (Figure 6). In contrast, the lung homogenates of young mice had significantly higher levels of IFN- $\gamma$ (on day 2 after inoculation), IL-2 (on days 2 to 5 after inoculation), IL-10 (on days 0 , and 2 to 5 after inoculation), and IL-13 (on days 0 to 2, and 4 and 5 after inoculation). Notably, the lung homogenates of preinfected adult mice (day 0) had higher IL-4 and lower IL-10 and IL-13 levels than young murine lungs. These observations indicate that the patterns of cytokine/chemokines responses are different between young and adult mice after SARS-CoV infection. Adult mice showed early and acutely excessive proinflammatory responses in the lung after SARS-CoV infection.

\section{Effect of Injecting Anti-TNF- $\alpha$ Antibody or IFN- $\gamma$ on the Pathogenesis of Mouse-Adapted SARS-CoV in Adult Mice}

To determine whether the TNF- $\alpha$ response of the adult mice and the IFN- $\gamma$ produced by the young but not adult mice played significant roles in the development of SARS-like illness by the F-musX-VeroE6-infected adult mice, we treated adult mice with an anti-TNF- $\alpha$ antibody or IFN- $\gamma 3$ hours after infection (Figure 7, A and $\mathrm{B}$ ). Although the intravenous injection with antiTNF- $\alpha$ antibody delayed the onset of this weight loss in the infected adult mice, as well as the onset of respiratory illness, both the anti-TNF- $\alpha$ antibody-treated and control adult mice showed significant body weight loss up until 6 days after inoculation and there were no significant differences in mortality rates between treated and control adult mice (treated adult mice: $62.5 \%, 50 \%$ mortality rate; control adult mice: $37.5 \%, 37.5 \%$ mortality rate in two separate experiments) (Figure 7A). In contrast, the IFN- $\gamma$-treated mice rapidly recovered from the illness as evidenced by their body weight loss and severe acute respiratory symptoms and all animals survived after onset 3 days after inoculation (Figure 7B). In contrast, 50\% of the control adult mice died.

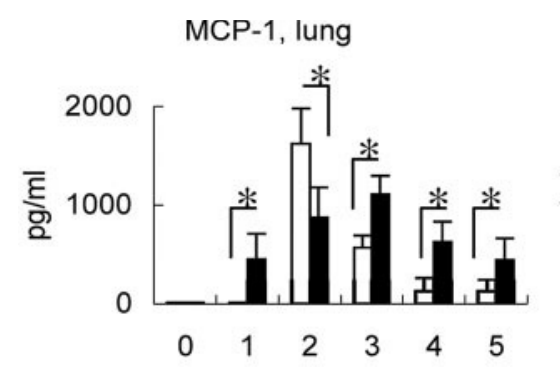

KC, lung

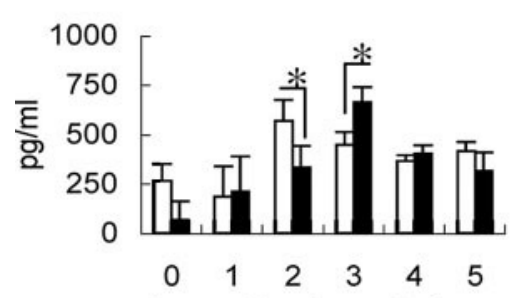

days after inoculation
MIP-1, lung

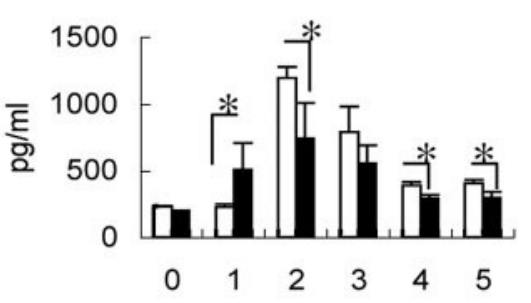

MIG, lung

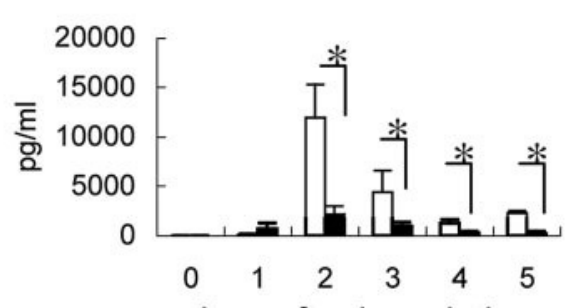

days after inoculation
IP-10, lung

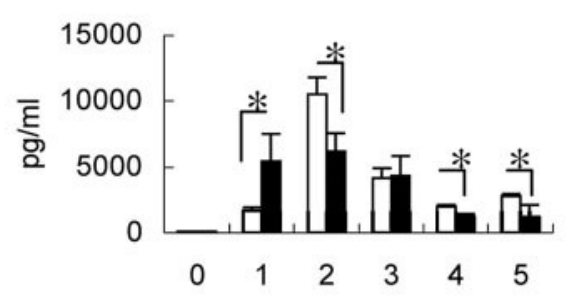

VEGF, lung

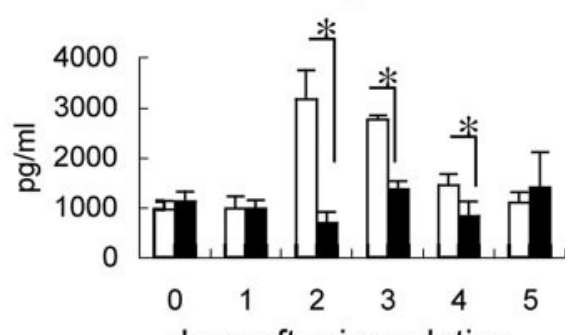

days after inoculation

Figure 5. Chemokine protein levels in the lungs of young (white bar) and adult (black bar) mice throughout time after inoculation ( $n=3$ per group). Asterisks indicate statistically significant higher or lower chemokine levels in adult mice $(P<0.05)$ compared to young BALB/c mice. Adult mice showed earlier induction of MCP-1, MIP-1, and IP-10 in the lungs than young mice but these three chemokines and MIG and VEGF were at significantly higher levels in the lungs of young mice on day 2 after inoculation. 
IL-1 $\alpha$, lung

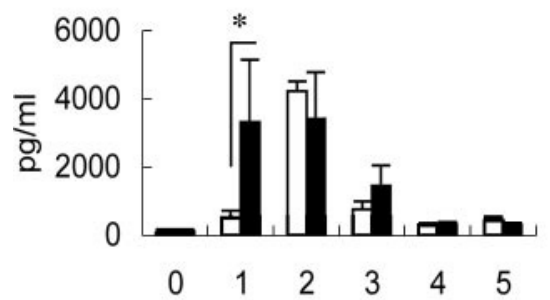

TNF- $\alpha$, lung
IL-1 $\beta$, lung

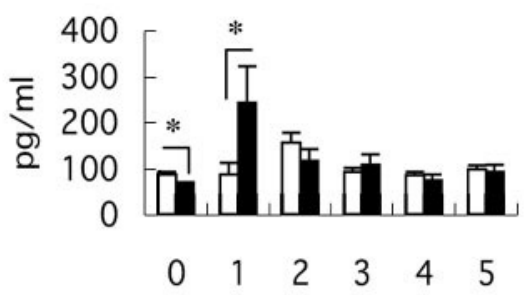

TNF-a, plasma

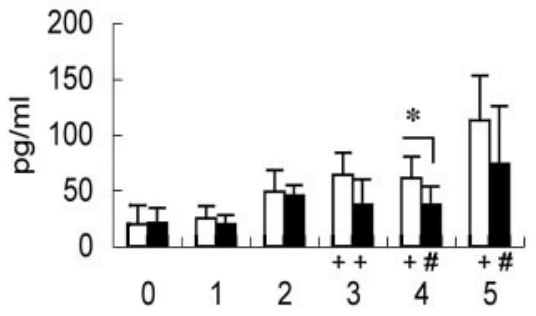

IFN- $\gamma$, lung
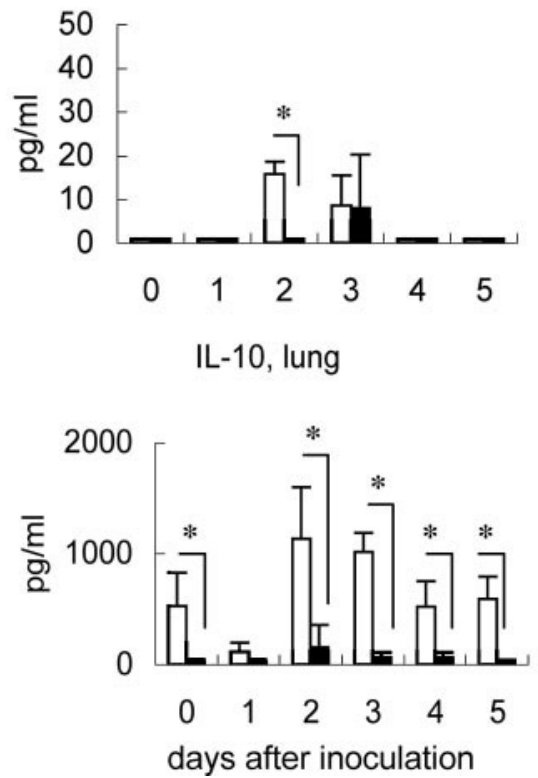

IL-6, lung

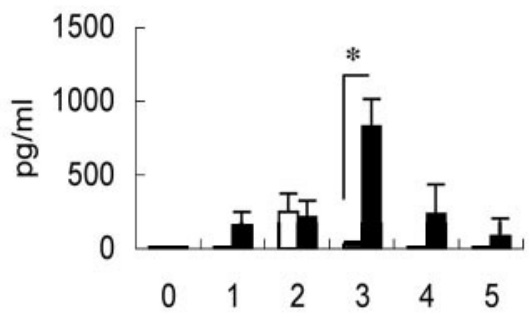

IL-2, lung

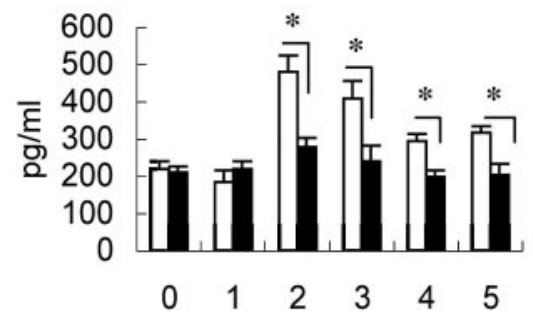

IFN- $\gamma$, plasma
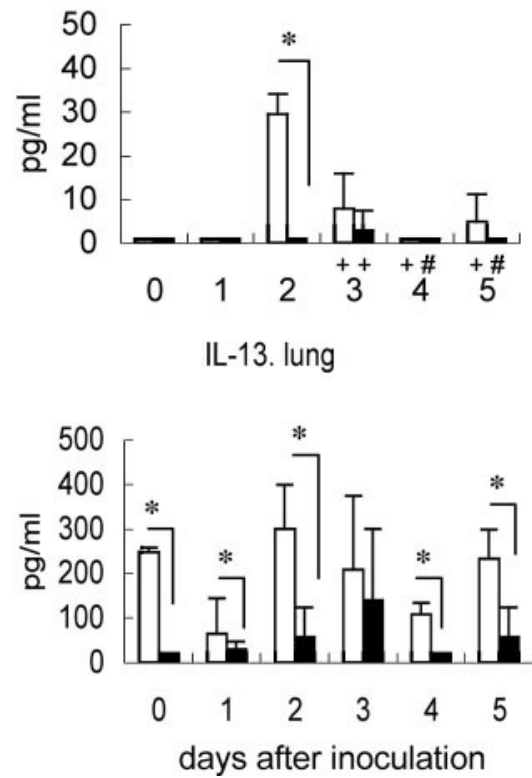

Figure 6. Cytokine protein levels in lungs and plasma throughout time after inoculation $\left(n=3\right.$ per group; $\left.{ }^{+} n=6 ;{ }^{*} n=4\right)$. Asterisks indicate statistically significant higher or lower cytokine levels in adult mice $(P<0.05)$ compared to in young mice. The adult mice had significantly higher levels of IL- $\alpha$, IL- $1 \beta$, IL-6, TNF- $\alpha$, and IL- 4 whereas the young mice had significantly higher levels of IL-2, IL-12, IFN- $\gamma$, IL-10, and IL-13.

To determine whether the protective effect of IFN- $\gamma$ treatment is attributable to suppression of viral replication, the virus titers on the day 3 after inoculation of nasal washes, maxilla homogenates, lung washes, and lung homogenates of IFN- $\boldsymbol{\gamma}$-treated and PBS-treated adult mice after the infection were compared. However, the two groups did not differ significantly in terms of virus titers in the respiratory tracts (Figure 7C). The IFN- $\gamma$-treated mice showed much milder histopathological changes than the untreated mice because only very mild edema with slight mononuclear cell infiltration was observed around the blood vessels after the infection (Figure 7D). In contrast, the PBS-treated mice exhibited severe edema and infiltration of inflammatory cells, mainly neutrophils, around blood vessels (Figure 7E). By examining Evans blue dye extravasation, we found the IFN- $\gamma$ treated mice also had lower blood vessel permeability than the PBS-treated mice (Figure 8, A-G). Together, these results suggest that IFN- $\gamma$ treatment 3 hours after inoculation protected the mice from severe SARS-CoVinduced pulmonary edema that was responsible for the death of the untreated adult mice. 
A

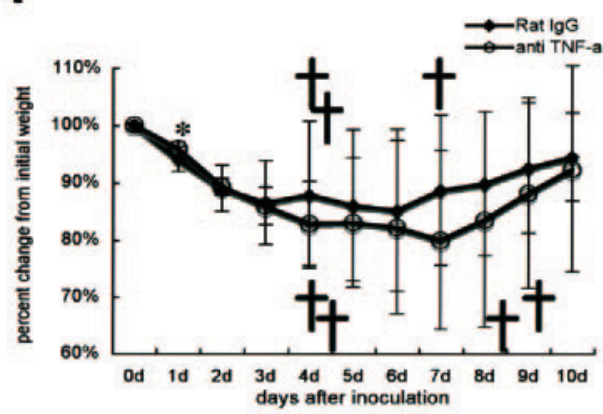

B

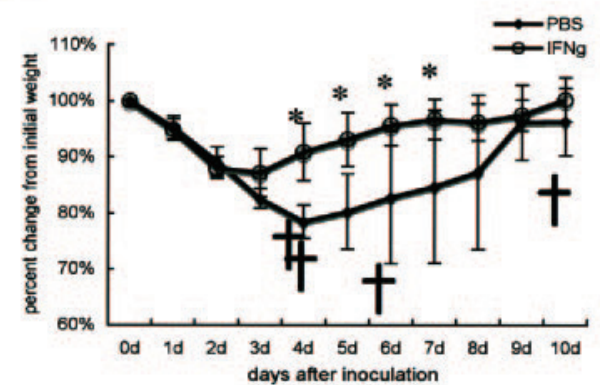

C

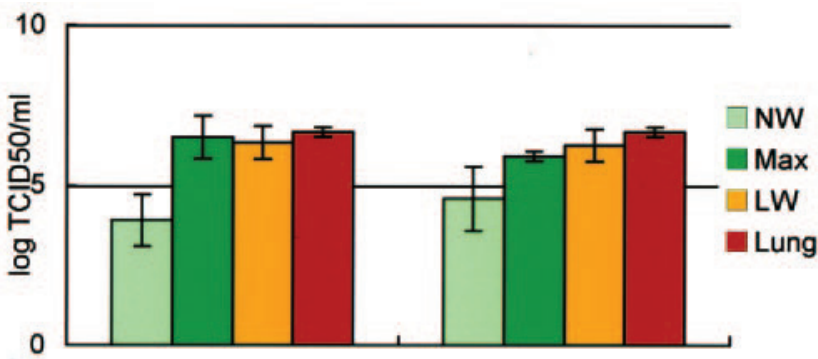

virus-IFN- $\gamma$

virus-PBS

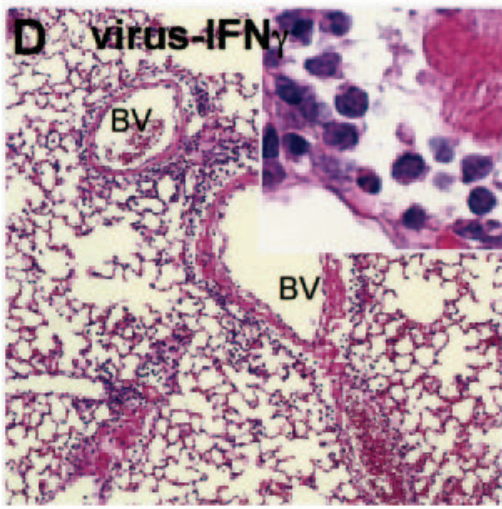

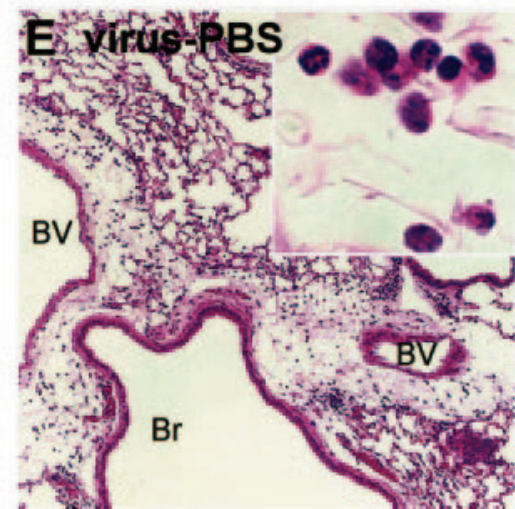

Figure 7. Effect of anti-TNF- $\alpha$ antibody or IFN- $\gamma$ injections of infected adult mice on body weight change throughout time after inoculation. Adult mice were infected with F-musX-VeroE6 by intranasal inoculation and injected intravenously with anti-TNF- $\alpha$ antibody or intraperitoneally with IFN- $\gamma 3$ hours after inoculation. Mean percentages of body weight change of the animals were determined for 10 days after inoculation. Crosses indicate dead mice. Asterisks indicate statistically significant differences in weight loss $(P<0.05)$ compared to control animals. The results shown in each panel are representative of at least two independent experiments for each panel ( $n=5$ to 8 per group). A: Effect of anti-TNF- $\alpha$ antibody ( $n=8$ per group). The control group was injected intravenously with rat IgG. B: Effect of IFN- $\gamma(n=8$ per group). The control group was injected with PBS intraperitoneally. C: Virus titers in the nasal (pale green bar) and lung (yellow bar) wash fluids and homogenates of the maxilla (including nasal cavity, green bar) and lung (orange bar) on days 3 after inoculation of PBS- and IFN- $\gamma$-treated adult mice ( $n=3$ per group). The detection limit was $10^{1.5} \mathrm{TCID}_{50} / \mathrm{g}$ of tissue. $\mathbf{D}$ and $\mathbf{E}$ : Lung histopathology in IFN- $\gamma$ - and PBS-treated adult mice, respectively. BV, blood vessel; Br, bronchi. Mononuclear cell infiltration was seen in the alveolar area and around blood vessels in the lungs of the IFN- $\gamma$-injected mice $(\mathbf{D}$, inset). In contrast, the lungs of PBS-injected mice exhibited polynuclear leukocyte infiltration around edematous blood vessels (E, inset)

\section{Discussion}

To understand better the pathogenesis of SARS after SARS-CoV infection, we developed a useful experimental mouse model of SARS. When the Frankfurt 1 isolate of SARS-CoV was serially passaged in vivo in young BALB/C mice, the passaged virus (F-musX-VeroE6) exhibited in- creased infectivity in the murine lung. F-musX-VeroE6 was also able to induce severe SARS-like illness in adult (6-month-old) BALB/c mice and several animals died of severe pulmonary edema and acute alveolar damage. However, young (4-week-old) mice were relatively resistant to F-musX-VeroE6 and did not evince any obvious respiratory illness. When the immune responses of in-
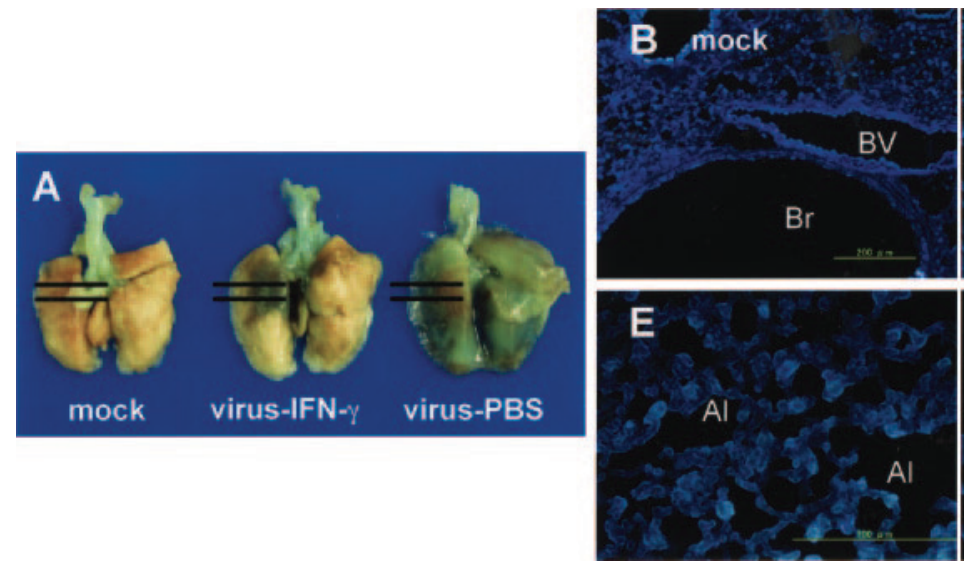
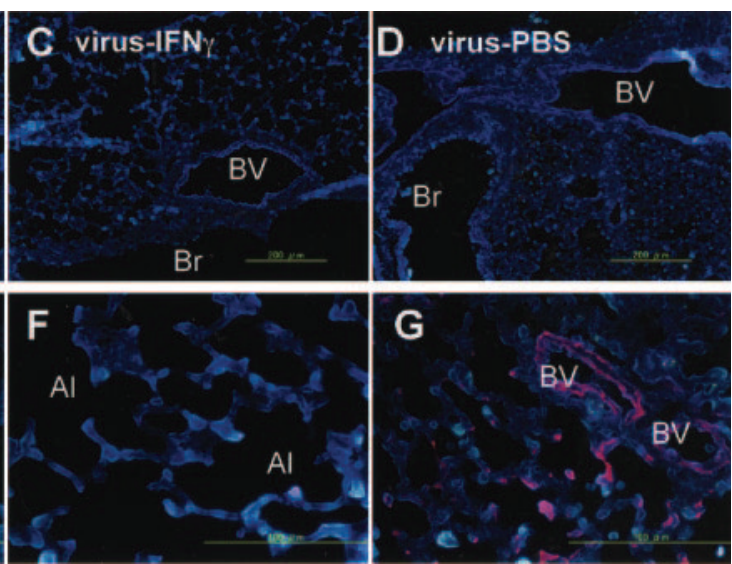

Figure 8. A-G: IFN- $\gamma$ treatment protects mice from infection-induced blood vessel hyperpermeability in the lung. Virus-infected adult mice ( $n=3$ ) were injected intraperitoneally with IFN- $\gamma$ or PBS and the effect of these treatments on lung blood vessel permeability was determined by using Evans blue dye extravasation. A: Blue discoloration of the lung tissue of IFN- $\gamma$ - and PBS-treated mice 3 days after inoculation. The black lines indicate the areas examined in more detail in $\mathbf{B}-\mathbf{G}$. B-G: The deposition of Evans blue dye in lung tissue (pink) was examined in frozen sections of the formalin-fixed tissue by using a fluorescence microscope. Scale bars: $200 \mu \mathrm{m}(\mathbf{B}-\mathbf{D})$; $100 \mu \mathrm{m}(\mathbf{E}-\mathbf{G})$. 
fected young and adult mice were compared, the adult animals had significantly lower pre-existing lymphocyte and $\mathrm{CD}^{+}$and $\mathrm{CD} 8^{+} \mathrm{T}$-cell counts, their lungs expressed significantly higher IL-4 and lower IL-10 and IL-13 levels before infection, and their lungs did not show the strong up-regulation of IL-2 (a T-cell cytokine), IL-10, IL-13, and IFN- $\gamma$ that was exhibited by the young murine lungs after infection. During the infection, the lungs of adult mice also produced inflammatory chemokine-/cytokine-related macrophages (ie, MCP-1, MIP-1 and IP-10, IL-1 $\alpha, \mathrm{IL}-1 \beta$, and TNF- $\alpha$ ) earlier than young mice (day 1 after inoculation) and at higher levels. They also had higher IL-6 levels on day 3 after inoculation. In contrast, the young mice produced high levels of inflammatory chemokines and cytokines (ie, MCP-1, MIP-1, IP-10, KC, MIG, VEGF, and $\mathrm{IL}-1 \alpha)$ on day 2 after inoculation and produced very little IL-6 at any time point. These observations suggest that advanced-age BALB/C mice have an early and acutely excessive proinflammatory cytokine reactions (ie, a cytokine storm) in response to F-musX-VeroE6. This cytokine storm results in severe pulmonary edema with macrophage and neutrophil infiltration, which causes severe acute lung injury and is likely to be the cause of death in infected adult mice. Supporting this scenario are reports of age-related differences in pulmonary cytokine and chemokine responses to other pathogens, especially Th1 and Th2 cytokine imbalances. ${ }^{31-33}$

Moreover, recent reports showed that unregulated IFN responses during acute SARS prevented SARS-CoV-infected patients from switching from innate to adaptive immunity, ${ }^{39,40}$ and some reports described that IFN- $\gamma$ may be responsible for lung immunopathology in SARS patients. ${ }^{41,42}$ Interestingly, in our model, injection of IFN- $\gamma$ 3 hours after inoculation significantly reduced the acute pulmonary edema induced by infection. Notably, these protective effects of IFN- $\gamma$ injection were not associated with reductions in viral titers in the lung. This animal model and human results seem not to be consistent. However, these observations together suggest that the failure of the adult animals to produce IFN- $\gamma$, which is a prominent immunomodulator that plays a key role in host defense against intracellular pathogens, ${ }^{43,44}$ was responsible for their inability to control the excessive and pathogenic innate immune response to the virus in the lung. Supporting this is our previous study on the rat SARS model, which showed that although adult rats developed severe inflammatory reactions that led to pulmonary edema, all of the infected animals survived; significantly, the infected adult rats had similar cytokine profiles as infected adult mice except that they also produced IFN- $\gamma^{34}$ Thus, a strong and timely IFN- $\gamma$ response may be needed to prevent the immunopathology induced by SARS-CoV infection.

With regard to the inflammatory reactions in the F-musX-VeroE6-infected adult lung, our histopathological and chemokine/cytokine analyses suggested that on day 1 after inoculation, the affected respiratory epithelial cells and pulmonary macrophages released acute inflammatory chemokines (MCP-1, MIP-1, IP-10) and cytokines (IL-1, TNF- $\alpha$, IL-12). Thus, pulmonary macrophage activation associated with the release of TNF- $\alpha$ and IL-1 appears to predominate in the early phase of the inflammatory reaction in adults. TNF- $\alpha$ and IL-1 are classic acute inflammatory cytokines that recruit neutrophils and monocytes to the area of infection along with increasing vascular permeability, where they activate these cells so that they can eradicate the pathogens. However, when TNF- $\alpha$ is overexpressed, it can induce systemic clinical and pathological abnormalities such as depressing cardiac dysfunction and cardiomyocyte death. ${ }^{45,46}$ This double-edged aspect of TNF- $\alpha$ function may be why there were no effects of neutralizing TNF- $\alpha$ antibodies on SARS-CoV infection in this model. Supporting the key role of TNF- $\alpha$ in F-musX-VeroE6-induced immunopathology is that the lungs of the adult mice on days 3 and 5 after inoculation were infiltrated with predominantly neutrophils; these mice also exhibited neutrophilia. Young mice did not evince these changes. This suggested that infected adult mice produce TNF- $\alpha$, which then induces neutrophil-mediated inflammation in their lungs. Although the significance of this is not clear, high neutrophil infiltration in the lung is known to be the cause or the result of lung injury characterized by hyaline membrane formation and pulmonary edema. ${ }^{47}$ High neutrophil counts in human SARS cases have also been associated with poor outcomes. . $^{8,10}$

We observed in the anti-TNF- $\alpha$ antibody and IFN- $\gamma$ injection experiments that the control groups, which were injected 3 hours after infection with rat IgG serum intravenously or PBS intraperitoneally, showed body weight loss starting on day 1 after inoculation. In contrast, untreated mice (such as those shown in Figures $1 \mathrm{~F}$ and 2A) only started to lose weight on day 2 after inoculation. It may be that the injection with serum or PBS after the infection enhanced the pulmonary edema by hyperpermeability in the lung.

We previously reported that serial in vivo passage of SARS-CoV in F344 rats increased the infectivity of the virus in rats, and that this correlated with a single amino acid change in the virus receptor-binding domain of the $S$ protein. ${ }^{34}$ We detected the similar change in F-musXVeroE6 along with another amino acid change in the receptor-binding domain of the $\mathrm{S}$ protein in F-musXVeroE6. The amino acid change may be responsible, at least in part, for the increased replication of F-musXVeroE6 in the pulmonary tissue of BALB/c mice. ${ }^{12-15,34,48}$ Using another SARS-CoV isolate (Urbani), Roberts and colleagues $^{48}$ have described the development and characterization of the mouse-adapted strain MA15, which is lethal for young (6- to 8-week-old) female BALB/c mice after intranasal inoculation. Compared with the original Urbani isolate, the MA15 strain had six coding mutations that may have been responsible for the mouse adaptation and increased virulence of this strain. The fewer amino acid mutations in our mouse-adapted F-musX-VeroE6 strain may be responsible for the fact that it is less virulent than MA15.

In conclusion, we developed an experimental mouse animal model of SARS by using in vivo-passaged SARS$\mathrm{CoV}$ and $\mathrm{BALB} / \mathrm{c}$ mice. We found that the virus was lethal in adult mice because they generated an excessive innate immune response that induced lethal pulmonary 
edema and diffuse alveolar damage with infiltration of macrophages and neutrophils. IFN- $\gamma$ appears to play an important role in modulating the innate immune response because IFN- $\gamma$ treatment protected the animals from the lethal respiratory illness. This study, along with our previous study ${ }^{34}$ and studies of humans infected with SARSCoV during the SARS epidemic of winter of 2002 to $2003,{ }^{6-10}$ improve our understanding of SARS pathogenesis because they indicate that both advanced age and virus adaptation to a particular animal species may dictate the pathogenic capacity of SARS-CoV. The new experimental model described here may also be useful for elucidating the pathophysiology of SARS and for evaluating anti-SARS-CoV vaccine candidates and antiviral agents.

\section{Acknowledgments}

We thank Dr. John Ziebuhr for kindly supplying the Frankfurt 1 isolate; the colleagues of our institute, especially Ms. Mihoko Fujino, Ms. Michiyo Kataoka, and Mr. Ikuyoshi Hatano, for their technical assistance; Dr. Yasuko Tsunetsugu-Yokota and Dr. Yasushi Ami for valuable discussions; Dr. Rie Watanabe and Dr. Kazuya Shirato for their technical expertise in virus genome sequencing; Dr. Noriko Nakajima for her technical expertise in confocal laser-scanning microscopy and valuable discussions; and Dr. Yoshinobu Horiuchi and Dr. Masaki Ochiai for their technical experts in the LPS kinetic chromatogenic assay and valuable discussions.

\section{References}

1. Drosten C, Günther S, Preiser W, van der Werf S, Brodt HR, Becker S, Rabenau H, Panning M, Kolesnikova L, Fouchier RAM, Berger A, Burguière AM, Cinatl J, Eickmann M, Escriou N, Grywna K, Kramme S, Mariuguerra JC, Müller S, Rickerts V, Stürmer M, Vieth S, Klenk HD, Osterhaus ADME, Schmitz H, Doerr HW: Identification of a novel coronavirus in patients with severe acute respiratory syndrome. N Engl J Med 2003, 348:1967-1976

2. Fouchier RAM, Kuiken $T$, Schutten $M$, van Amerongen $G$, van Doornum GJJ, van den Hoogen BG, Peiris M, Lim W, Stöhr K, Osterhaus ADME: Koch's postulates fulfilled for SARS virus. Nature 2003, 423:240

3. Ksiazek TG, Erdman D, Goldsmith CS, Zaki SR, Peret T, Emery S, Tong S, Urbani C, Comer JA, Lim W, Rollin PE, Dowell SF, Ling AE, Humphrey CD, Shieh WJ, Guarner J, Paddock CD, Rota MPHTMP, Fields B, DeRisi J, Yang JY, Cox N, Hughes JM, LeDuc JW, Bellini WJ, Anderson LJ, the SARS Working Group: A novel coronavirus associated with severe acute respiratory syndrome. N Engl J Med 2003, 348:1953-1966

4. Kuiken T, Fouchier RAM, Schutten M, Rimmelzwaan GF, van Amerongen G, van Riel D, Laman JD, de Jong T, van Doornum G, Lim W, Ling AE, Chan PKS, Tam JS, Zambon MC, Gopal R, Drosten C, van der Werf S, Escriou N, Manuguerra JC, Stöhr K, Peiris JSM, Osterhaus ADME: Newly discovered coronavirus as the primary cause of severe acute respiratory syndrome. Lancet 2003, 362:263-270

5. Peiris JSM, Lai ST, Poon LLM, Guan Y, Yam LYC, Lim W, Nicholls J, Yee WKS, Yan WW, Cheung MT, Cheng VCC, Chan KH, Tsang DNC, Yung RWH, Ng TK, Yuen KY, members of the SARS Study Group: Coronavirus as a possible cause of severe acute respiratory syndrome. Lancet 2003, 361:1319-1325

6. Booth CM, Matukas LM, Tomlinson GA, Rachlis AR, Rose DB, Dwosh HA, Walmsley SL, Mazzulli T, Avendano M, Derkach P, Ephtimios IE, Kitai I, Mederski BD, Shadowitz SB, Gold WL, Hawryluck LA, Rea E,
Chenkin JS, Cescon DW, Poutanen SM, Detsky AS: Clinical features and short-term outcomes of 144 patients with SARS in the greater Toronto area. JAMA 2003, 289:2801-2809

7. Donnelly CA, Ghani AC, Leung GM, Hedley AJ, Fraser C, Riley S, Abu-Raddad LJ, Ho LM, Thach TQ, Chau P, Chan KP, Lam TH, Tse LY, Tsang T, Liu SH, Kong JH, Lau EM, Ferguson NM, Anderson RM: Epidemiological determinants of spread of causal agent of severe acute respiratory syndrome in Hong Kong. Lancet 2003, 361: $1761-1766$

8. Lee N, Hui D, Wu A, Chan P, Cameron P, Joynt GM, Ahuja A, Yung MY, Leung CB, To KF, Lui SF, Szeto CC, Chung S, Sung JJ: A major outbreak of severe acute respiratory syndrome in Hong Kong. N Engl J Med 2003, 348:1986-1994

9. Peiris JS, Chu CM, Cheng VC, Chan KS, Hung IF, Poon LL, Law KI, Tang BS, Hon TY, Chan CS, Chan KH, Ng JS, Zheng BJ, Ng WL, La RW, Guan Y, Yuen KY, HKU/UCH SARS Study Group: Clinical progression and viral load in a community outbreak of coronavirusassociated SARS pneumonia: a prospective study. Lancet 2003, 361:1767-1772

10. Tsui PT, Kwok ML, Yuen H, Lai ST: Severe acute respiratory syndrome: clinical outcome and prognostic correlates. Emerg Infect Dis 2003, 9:1064-1069

11. Li W, Moore MJ, Vasilieva N, Sui J, Wong SK, Berne MA, Somasundaran M, Sullivan JL, Luzuriaga K, Greenough TC, Choe H, Farzan M: Angiotensin-converting enzyme 2 is a functional receptor for the SARS coronavirus. Nature 2003, 426:450-454

12. Li W, Zhang C, Sui J, Kuhn JH, Moore MJ, Luo S, Wong SK, Huang IC, Xu K, Vasilieva N, Murakami A, He Y, Marasco WA, Guan Y, Choe H, Farzan M: Receptor and viral determinants of SARS-coronavirus adaptation to human ACE2. EMBO J 2005, 24:1634-1643

13. Li F, Li W, Farzan M, Harrison SC: Structure of SARS coronavirus spike receptor-binding domain complexed with receptor. Science 2005, 309:1864-1868

14. Li W, Greenough TC, Moore MJ, Vasilieva N, Somasundaran M, Sullivan JL, Farzan M, Choe H: Efficient replication of severe acute respiratory syndrome coronavirus in mouse cells is limited by murine angiotensin-converting enzyme 2. J Virol 2004, 78:11429-11433

15. Imai $Y$, Kuba K, Rao S, Huan Y, Guo F, Guan B, Yang P, Sarao R, Wada T, Leong-Poi H, Crackower MA, Fukamizu A, Hui CC, Hein L, Uhlig S, Slutsky AS, Jiang C, Penninger JM: Angiotensin-converting enzyme 2 protects from severe acute lung failure. Nature 2005, 436:112-116

16. Kuba K, Imai Y, Rao S, Gao H, Guo F, Guan B, Huan Y, Yang P, Zhang Y, Deng W, Bao L, Zhang B, Liu G, Wang Z, Chappell M, Liu Y, Zheng D, Leibbrandt A, Wada T, Slutsky AS, Liu D, Qin C, Jiang C, Penninger JM: A crucial role of angiotensin converting enzyme 2 (ACE2) in SARS coronavirus-induced lung injury. Nat Med 2005, 11:875-879

17. Gu J, Korteweg C: Pathology and pathogenesis of severe acute respiratory syndrome. Am J Pathol 2007, 170:1136-1147

18. Nicholls JM, Poon LL, Lee KC, Ng WF, Lai ST, Leung CY, Chu CM, Hui PK, Mak KL, Lim W, Yan KW, Chan KH, Tsang NC, Guan Y, Yuen KY, Peiris JS: Lung pathology of fatal severe acute respiratory syndrome. Lancet 2003, 361:1773-1778

19. Zhang Y, Li J, Zhan Y, Wu L, Yu X, Zhang W, Ye L, Xu S, Sun R, Wang $Y$, Lou J: Analysis of serum cytokines in patients with severe acute respiratory syndrome. Infect Immun 2004, 72:4410-4415

20. Okabayashi T, Kariwa H, Yokota S, Iki S, Indoh T, Yokosawa N, Takashima I, Tsutsumi H, Fujii N: Cytokine regulation in SARS coronavirus infection compared to other respiratory virus infections. J Med Virol 2006, 78:417-424

21. Gao W, Tamin A, Soloff A, D'Aiuto L, Nwanegbo E, Robbins PD, Bellini WJ, Barratt-Boyes S, Gambotto A: Effects of a SARS-associated coronavirus vaccine in monkeys. Lancet 2003, 362:1895-1896

22. McAuliffe J, Vogel L, Roberts A, Fahle G, Fischer S, Shieh W, Butler E, Zaki S, Claire MS, Murphy B, Subbarao K: Replication of SARS coronavirus administered into the respiratory tract of African Green, rhesus and cynomolgus monkeys. Virology 2004, 330:8-15

23. Qin C, Wang J, Wei Q, She M, Marasco WA, Jiang H, Tu X, Zhu H, Ren L, Gao H, Guo L, Huang L, Yang R, Cong Z, Guo L, Wang Y, Liu Y, Sun Y, Duan S, Qu J, Chen L, Tong W, Ruan L, Liu P, Zhang H, Zhang J, Zhang H, Liu D, Liu Q, Hong T, He W: An animal model of SARS produced by infection of Macaca mulatta with SARS coronavirus. J Pathol 2005, 206:251-259 
24. Rowe T, Gao G, Hogan RJ, Crystal RG, Voss TG, Grant RL, Bell P, Kobinger GP, Wivel NA, Wilson JM: Macaque model for severe acute respiratory syndrome. J Virol 2004, 78:11401-11404

25. Liang L, He C, Lei M, Li S, Hao Y, Zhu H, Duan Q: Pathology of guinea pigs experimentally infected with a novel reovirus and coronavirus isolated from SARS patients. DNA Cell Biol 2005, 24:485-490

26. Weingartl HM, Copps J, Drebot MA, Marszal P, Smith G, Gren J Andova M, Pasick J, Kitching P, Czub M: Susceptibility of pigs and chickens to SARS coronavirus. Emerg Infect Dis 2004, 10:179-184

27. Roberts A, Vogel L, Guarner J, Hayes N, Murphy B, Zaki S, Subbarao $\mathrm{K}$ : Severe acute respiratory syndrome coronavirus infection of golden Syrian hamsters. J Virol 2005, 79:503-511

28. Martina BE, Haagmans BL, Kuiken T, Fouchier RA, Rimmelzwaan GF, Van Amerongen G, Peiris JS, Lim W, Osterhaus AD: SARS virus infection of cats and ferrets. Nature 2003, 425:915

29. Roberts A, Paddock C, Vogel L, Butler E, Zaki S, Subbarao K: Aged BALB/c mice as a model for increased severity of severe acute respiratory syndrome in elderly humans. J Virol 2005, 79:5833-5838

30. Sandmand M, Bruunsgaard H, Kemp K, Andersen-Ranberg K, Pedersen AN, Skinhoj P, Pedersen BK: Is ageing associated with a shift in the balance between type 1 and type 2 cytokines in humans? Clin Exp Immunol 2002, 127:107-114

31. Looney RJ, Falsey AR, Walsh E, Campbell D: Effect of aging on cytokine production in response to respiratory syncytial virus infection. J Infect Dis 2002, 185:682-685

32. Antonini JM, Roberts JR, Clarke RW, Yang HM, Barger MW, Ma JY Weissman DN: Effect of age on respiratory defense mechanisms: pulmonary bacterial clearance in Fischer 344 rats after intratracheal instillation of Listeria monocytogenes. Chest 2001, 120:240-249

33. Boukhvalova MS, Yim KC, Kuhn KH, Hemming JP, Prince GA, Porter DD, Blanco JC: Age-related differences in pulmonary cytokine response to respiratory syncytial virus infection: modulation by antiinflammatory and antiviral treatment. J Infect Dis 2007, 195:511-518

34. Nagata N, Iwata N, Hasegawa H, Fukushi S, Yokoyama M, Harashima A, Sato Y, Saijo M, Morikawa S, Sata T: Participation of both host and virus factors in induction of severe acute respiratory syndrome (SARS) in F344 rats infected with SARS coronavirus. J Virol 2007, 81:1848-1857

35. Inoue G: Effect of interleukin-10 (IL-10) on experimental LPS-induced acute lung injury. J Infect Chemother 2000, 6:51-60

36. Fukushi S, Mizutani T, Saijo M, Matsuyama S, Miyajima N, Taguchi F, Itamura S, Kurane I, Morikawa S: Vesicular stomatitis virus pseudotyped with severe acute respiratory syndrome coronavirus spike protein. J Gen Virol 2005, 86:2269-2274

37. Liem NT, Nakajima N, Phat LLP, Sato Y, Thach HN, Hung PV, San LT, Katano H, Kumasaka T, Oka T, Kawachii S, Matsushita T, Sata T,
Kudo K, Suzuki K: H5N1-infected cells in lung with diffuse alveolar damage in exudative phase from a fatal case in Vietnam. Jpn J Infect Dis 2008, 61:157-160

38. Ohnishi K, Sakaguchi M, Kaji T, Akagawa K, Taniyama T, Kasai M, Tsunetsugu-Yokota Y, Oshima M, Yamamoto K, Takasuka N, Hashimoto S, Ato M, Fujii H, Takahashi Y, Morikawa S, Ishii K, Sata T, Takagi H, Itamura S, Odagiri T, Miyamura T, Kurane I, Tashiro M, Kurata T, Yoshikura H, Takemori T: Immunological detection of severe acute respiratory syndrome coronavirus by monoclonal antibodies. Jpn J Infect Dis 2005, 58:88-94

39. Cameron MJ, Bermejo-Martin JF, Danesh A, Muller MP, Kelvin DJ: Human immunopathogenesis of severe acute respiratory syndrome (SARS). Virus Res 2008, 133:13-19

40. Cameron MJ, Ran L, Xu L, Danesh A, Bermejo-Martin JF, Cameron CM, Muller MP, Gold WL, Richardson SE, Poutanen SM, Willey BM, Devries ME, Fang Y, Seneviratne C, Bosinger SE, Persad D, Wilkinson P, Greller LD, Somogyi R, Humar A, Keshavjee S, Louie M, Loeb MB, Brunton J, McGeer AJ, Kelvin DJ: Interferon-mediated immunopathological events are associated with atypical innate and adaptive immune responses in severe acute respiratory syndrome (SARS) patients. J Virol 2007, 81:8692-8706

41. Theron M, Huang KJ, Chen YW, Liu CC, Lei HY: A probable role for IFN-gamma in the development of a lung immunopathology in SARS. Cytokine 2005, 32:30-38

42. Huang KJ, Su IJ, Theron M, Wu YC, Lai SK, Liu CC, Lei HY: An interferon-gamma-related cytokine storm in SARS patients. J Med Virol 2005, 75:185-194

43. Schultz RM, Kleinschmidt WJ: Functional identity between murine gamma interferon and macrophage activating factor. Nature 1983 305:239-240

44. Noble A, Macary PA, Kemeny DM: IFN-gamma and IL-4 regulate the growth and differentiation of CD8+ T cells into subpopulations with distinct cytokine profiles. J Immunol 1995, 155:2928-2937

45. Natanson C, Eichenholz PW, Danner RL, Eichacker PQ, Hoffman WD, Kuo GC, Banks SM, MacVittie TJ, Parrillo JE: Endotoxin and tumor necrosis factor challenges in dogs simulate the cardiovascular profile of human septic shock. J Exp Med 1989, 169:823-832

46. Meldrum DR: Tumor necrosis factor in the heart. Am J Physiol 1998 274:577-595

47. Ware LB, Matthay MA: The acute respiratory distress syndrome N Engl J Med 2000, 342:1334-1349

48. Roberts A, Deming D, Paddock CD, Cheng A, Yount B, Vogel L, Herman BD, Sheahan T, Heise M, Genrich GL, Zaki SR, Baric R, Subbarao K: A mouse-adapted SARS-coronavirus causes disease and mortality in BALB/c mice. PLOS Pathogens 2007, 3:23-37 